\title{
O DIREITO E A RELAÇÃO COM A PESSOA COM DEMÊNCIA
}

Hosni, David Salim Santos. Pessoalidade e identidade na doença de Alzheimer: cautela e inclusão no Estatuto da Pessoa com Deficiência. Rio de Janeiro: Lumen Juris, 2018, p. 175218.

\section{Washington Luiz Ferreira Dias Lopes*}

Receber o diagnóstico de que se possui determinada enfermidade mental, como a doença de Alzheimer, é receber uma sentença de incapacidade absoluta? É possível ter algum grau de autonomia e identidade na tomada de decisões sendo portador de algum um tipo de demência? O discernimento deve ou não ser um critério determinante para uma pessoa ser representada pelo instituto da curatela? Buscar respostas a essas reflexões é a proposta da presente obra.

Após o advento do Estatuto da Pessoa com Deficiência (Lei 13.146 de 6 de julho de 2015), David Hosni apresenta, em sua obra Pessoalidade e identidade na doença de Alzheimer: curatela e inclusão no Estatuto da Pessoa com Deficiência, uma série de pesquisas e críticas acerca do tratamento dispensado ao possuidor da doença de Alzheimer, como a jurisprudência tem tratado o instituto da curatela e compreendido a autonomia, a identidade e o discernimento do indivíduo que apresenta essa patologia degenerativa.

Enquanto a recente legislação tem sido alvo de frequentes críticas negativas, Hosni caminha rente à ideia de que referido ordenamento mais protege do que coloca em risco seu público-alvo. No caso da demência de Alzheimer, por exemplo, as alterações promovidas pela nova lei expandiram o grau de guarita ao restringir o instituto da curatela às questões patrimoniais e permitir que o portador da enfermidade, respeitadas as limitações e os avanços da doença, possa exercer sua autonomia, sem perder sua identidade, em outros campos da vida civil.

O capítulo quatro da obra, especificamente, trata da relação existente entre o Direito e a pessoa com deficiência. Hosni questiona os limites éticos e as consequências da delimitação

Resenha submetida em 13 de abril de 2020 e aprovada em 31 de agosto de 2020.

*Advogado. Mestrando em Direito Pela Universidade Federal De Ouro Preto. Bacharel em Direito pela Faculdade Mineira de Direito da Pontifícia Universidade Católica de Minas Gerais. E-mail: washington.diaslopes@hotmail.com. 
pelo legislador do conceito de personalidade (pessoalidade).

O que é positivado, afirma o autor, quase sempre caminha distante da realidade, dada a sua característica generalista. Esse fato é percebido, por exemplo, quando surge a necessidade, no próprio Código Civil em vigor, de se separarem as pessoas de acordo com seus elementos pessoais, que, por sua vez, culminarão em uma maior ou menor participação social.

É por meio dessas definições, que, por vezes, ultrapassam os aspectos legais e esbarram no entendimento da jurisprudência, que se chega a um denominador comum em assuntos como aborto, direitos do nascituro, suicídio assistido e direito de imagem, em que todos partem do entendimento basilar sobre o que é e como se dá a personalidade, que vai muito além da simples definição de adquirir direitos e deveres.

Sobre o Estatuto da Pessoa com Deficiência, Hosni explica que ele trouxe alterações ao regime de incapacidades da lei anterior, que, apesar de descomplicado, não era mais considerado "apto a lidar com as nuances da vida diária e das necessidades do incapaz" (HOSNI, 2018, p. 182-183), além de dar a impressão de proteger o indivíduo apenas em nível patrimonial.

Isso porque o próprio Código Civil de 2002 não orientava o curador, além de não haver sequer algum tipo de princípio sobre os parâmetros de decisão em questões de cunho pessoal e existencial, e, mesmo que fossem previstos, no caso de uma pessoa com demência, a própria sentença é incapaz de apontar qual seria a melhor decisão para os interesses do curatelado em cada caso, considerando a pessoa com demência em seus aspectos presentes e passados.

A novidade trazida pelo Estatuto com a exclusão da possibilidade de incapacidade absoluta ao demente e a manutenção do instituto da curatela pela nova sistemática, não apenas do Código Civil, mas do novo Código de Processo Civil, revelam-se um importante apoio à autonomia do interdito, cabendo aos tribunais firmarem entendimentos sobre como esse apoio ocorrerá em termos práticos.

Logo, mais do que um diploma normativo recheado de boas intenções, o Estatuto da Pessoa com Deficiência, na opinião do autor, surge como resultado da compreensão da deficiência (nesse caso, da demência) de uma maneira diferente da que era vigente até então, ainda que a referida legislação apresente erros técnicos e inconsistências jurídicas.

Hosni entende que é preciso ir além do significado de discernimento, pois somente quando existirem parâmetros que levem em consideração a vontade da pessoa afetada pela 
doença de Alzheimer, refletindo de maneira expressa sobre situações importantes vivenciadas pelo afetado por esta enfermidade, é que a lei conseguirá uma proteção efetiva, o que está longe de acontecer.

É necessário que seja realizada uma análise sobre qual vontade do portador de uma demência será levada em conta: a vontade anterior à enfermidade, que era exercida de maneira livre e informal, ou a vontade posterior, atual, em que a pessoa já apresenta perdas cognitivas. Além disso, há que se realizar um aprofundamento sobre o conhecimento da realidade das pessoas que convivem com essas enfermidades, suas disfunções, questões éticas e empíricas, para que a proteção adequada a esses indivíduos possa ser exercida.

Sobre a aplicação do instituto da curatela ao deficiente na doença de Alzheimer, Hosni destaca que esses casos, em um primeiro momento, devem ser interpretados em consonância com as condições específicas do Estatuto da Pessoa com Deficiência, ainda que, para alguns, exista um confronto de entendimentos relacionados às previsões no Código Civil, no Código de Processo Civil e no próprio Estatuto, que levam a crer na possibilidade desta curatela ser deferida sem declaração de incapacidade, ante a atecnia da Lei. Em um segundo momento, a partir da compreensão dos dispositivos da lei de deficiência, buscar-se-á uma generalização para que o modelo funcional de curatela seja aplicado, sempre considerando a limitação de desempenho e a restrição de participação do deficiente.

O instituto da curatela, no novo modelo proposto, será efetivo quando a incapacidade por ele tratada for baseada no construto da deficiência, em que se avalia o contexto global da saúde do deficiente, capaz de demonstrar os limites da curatela nas situações específicas em que os recursos psicossociais não forem capazes de viabilizar o exercício de funções e direitos por parte do portador da doença.

Portanto, conclui, o autor, que só deverá ser submetido à curatela, aquele deficiente que for incapaz de transmitir a sua própria vontade, logo, relativamente incapaz, seja qual for a sua deficiência. No caso da Doença de Alzheimer, que é uma patologia neurodegenerativa cognitiva progressiva, que afeta a pessoa, reduzindo suas capacidades cognitivas de naturezas diversas, a imposição da curatela deverá partir da análise da relação do indivíduo com o ambiente em que vive, para que os limites da curatela sejam estabelecidos, posto que se trata de medida extraordinária.

É preciso, por parte não só dos profissionais do Direito, que exista uma compreensão acerca da autonomia e da proteção do vulnerável. No caso específico da doença de Alzheimer, diagnosticada em seu estágio inicial, em que o enfermo ainda é capaz de desenvolver de 
maneira autônoma diversas funções em vários aspectos da vida social, deferir de plano a curatela pode ser uma medida extrema. É necessário que o Direito seja um caminho de orientação para que esse sujeito leve a vida com o máximo de segurança (e, aqui, inclui-se a segurança jurídica dos atos por ele praticados) e bem-estar.

Nesse sentido, Hosni defende que a responsabilidade pelo tratamento e balanceamento da proteção da autonomia do enfermo mental é conjunto e envolve, não apenas o curador com suas obrigações, mas o poder público com o dever de fiscalizar e exigir seu cumprimento, e destaca que, mesmo na curatela, o melhor caminho para que haja o respeito à autonomia e à vontade do curatelado é o diálogo, visto que se trata de um sujeito de direitos e deveres cujas decisões afetam sua saúde e bem-estar, e não de um objeto de cuidado, de modo que a tarefa mais árdua, seja para um juiz, um promotor ou um curador, é fazer o juízo de qual ou quais vontades da pessoa com deficiência mental devem prevalecer em determinados momentos.

Portanto, não se trata apenas de uma aplicação da nova lei direcionada aos deficientes, mas do desenvolvimento de uma tarefa interpretativa como instrumento fundamental de solução de problemas surgidos a partir da promulgação do Estatuto da Pessoa com Deficiência, no sentido de garantir a real autonomia daquele que apresenta enfermidade mental, considerando outros aspectos da vida além do critério do discernimento comprometido, em consonância com o princípio constitucional da dignidade da pessoa humana.

Fato é que, o Estatuto da Pessoa Com Deficiência, ainda que seja alvo de críticas, representa um importante passo inicial rumo à inclusão do deficiente, posto que a lei não é capaz de impor, por si só, uma mudança cultural na sociedade mas, configura-se num instrumento que permite a abertura de um caminho de maior aceitação destes indivíduos. 